\title{
LINGKAR KUASA KEHIDUPAN KOMUNITAS PEMULUNG PANDESARI KOTA MALANG
}

\author{
Lutfi Amiruddin \\ Pengelolaan Infrastruktur dan Pembangunan Masyarakat Sekolah \\ Pascasarjana Universitas Gadjah Mada \\ Email: amiruddin_lutfi@yahoo.com
}

\begin{abstract}
The study of the scavenger ('pemulung') community of Pandesari, Malang, is important describe in detail the social process behind the scavenger phenomena, one sometimes caused by local government's policies which neglect their conditions. Urban people need residences and jobs, thus to avoid poverty many of them became scavengers. The scavengers are subordinated under a "boss" ('pengepul'), who also employs sorters and the weighers. There are four results of this paper. First, research shows that the boss achieves power through a patron-client relationship, which ensures that the scavengers are dependent on the boss. Second, research shows that there has been exploitation in the scavenger community, in which the scavengers are exploited and the boss is an exploiter. Third, research shows that resistance from the scavengers emerges as the result of the exploitation from which they suffer. Fourth, research shows issues with Scott's view regarding patron-client relationships in that the sorter and the weigher are the members of community who are given special authority from the elite power, with a role in strengthening the power of elite community. They are "the right hand" of the elite community who strengthen and protect its power.
\end{abstract}

Keywords: Patron Client Relationship, Exploitation, Resistance, "The Right Hand"

\begin{abstract}
ABSTRAK
Penelitian mengenai komunitas pemulung Pandesari Kota Malang menjadi penting untuk menjelaskan secara mendalam proses sosial yang terjadi, karena pemerintah seringkali melupakan kondisi komunitas tersebut. Kaum urban ini membutuhkan pemukiman sekaligus pekerjaan yang membuat mereka bekerja sebagai pemulung. Dengan menjadi pemulung, mereka kemudian dijadikan faktor produksi oleh pengepul. Di samping pemulung, juga terdapat pemilah dan penimbang. Terdapat beberapa temuan dalam penelitian ini. Pertama, pengepul mendapatkan kekuasaannya melalui hubungan patron klien, yang menempatkan pemulung bergantung kepadanya. Kedua, terjadi eksploitasi dalam komunitas Pandesari, yang menempatkan pemulung sebagai golongan yang tereksploitasi, sedangkan pengepul yang mengeksploitasi. Ketiga, pemulung melancarkan perlawanan sebagai akibat dari eksploitasi yang diterimanya. Keempat, temuan penelitian sekaligus merupakan kritik terhadap pendapat Scott, yang menunjukkan bahwa pemilah dan penimbang dengan wewenang khususnya merupakan "tangan kanan" elite komunitas. Tugas mereka adalah memperkuat dan melindungi kekuasaan.
\end{abstract}

Kata kunci: Hubungan Patron-Klien, Eksploitasi, Perlawanan, "Tangan Kanan" 


\section{PENGANTAR}

Sebagai salah satu bagian dari kelompok miskin perkotaan, pemulung dikenal karena memiliki pekerjaan khusus; mengumpulkan sampah yang kemudian dikumpulkan dan dijual kepada pengepul. Mereka biasa menyusuri jalan-jalan di perkampungan warga perkotaan untuk mengais sampah yang ada. Kondisi pemulung di belahan bumi lainnya pun tidak jauh berbeda seperti yang dilaporkan oleh Birkbeck mengenai keberadaan pemulung di Kota Cali, Colombia. Proporsi barang pulungan yang potensial untuk dijual, dikumpulkan dan diawali oleh para pemulung dengan cara-cara mereka sendiri dan sebagian besar hasilnya untuk pabrik-pabrik besar (Birkbeck dalam Gilbert dan Gugler, 1996: 100).

Sebagai kota terbesar kedua di Jawa Timur setelah Surabaya, Malang memiliki daya tarik yang menggiurkan bagi mereka yang ingin mengubah nasib. Di sektor informal, muncul komunitas pemulung yang salah satunya berada di daerah Pandesari di tepian Sungai Tambak. Mereka tinggal berkelompok dalam suatu lingkungan komunitas, yang terdiri dari beberapa rumah gubuk yang saling berhimpitan satu sama lain. Di tempat itu mereka bertempat tinggal, bekerja, berkeluarga, berinteraksi, dan bersosialisasi satu sama lain, serta bertahan hidup di tengah kerasnya persaingan kehidupan kota.

Komunitas pemulung Pandesari memiliki kepala komunitas sebagai pemimpin. Dia bertugas sebagai ketua, koordinator, dan pengepul atau juragan dari para pemulung, penimbang, dan pemilah yang tinggal di komunitas tersebut. Di tempat ini pula, dia tinggal berdampingan dengan pemulung, penimbang, dan pemilah yang dipimpinnya. Pemulung, penimbang, dan pemilah memiliki tugas masing-masing yang berbeda satu sama lain.

Deskripsi di atas mengimplikasikan beberapa hal, antara lain; pertama, pengepul menjadi golongan yang memiliki sekaligus menguasai faktor produksi berupa tenaga kerja, yang terdiri dari pemulung, pemilah, dan penimbang. Pengepul - meskipun tidak memiliki, namun menguasai faktor produksi berupa lahan. Kedua, para pekerja akan semakin tergantung dengan pengepulnya yang telah menyediakan pekerjaan dan tempat tinggal untuknya. Dalam penelitian ini, pengepul kemudian diidentifikasi sebagai kelas elite komunitas. Adapun para pekerja seperti pemulung, pemilah, dan penimbang diidentifikasi sebagai kelas anggota komunitas.

Melalui penelitian ini, menjadi menarik untuk mengidentifikasi mengenai bagaimana proses elite komunitas tersebut mendapatkan kekuasaan atas faktor-faktor produksi di atas. Hal ini penting karena komunitas pemulung merupakan bagian dari masyarakat perkotaan yang seringkali diasumsikan memiliki norma dan nilai yang berbeda dengan kelompok lain. Atas asumsi ini pula seringkali berbagai macam kebijakan pemerintah justru tidak memihak pada kelompok masyarakat miskin seperti pemulung. Sebab, inti dari relasi-relasi sosial yang ada di dalamnya seringkali belum tergambarkan secara komperhensif.

Penelitian pada komunitas pemulung Pandesari diilhami oleh pandangan James C. Scott yang merupakan sintesis dari masyarakat petani desa. Terdapat tiga konsep penting dalam kerangka teoretik dalam tulisan ini, yaitu, kekuasaan, eksploitasi, dan perlawanan (resistensi).

Pertama, konsep kekuasaan. Ini diasumsikan bahwa faktor ekonomi saja tidak cukup mampu memberikan kekuasaan dalam sebuah masyarakat, namun nilai dan norma juga sangat berperan dalam memberikan kekuasaan. Tujuan yang terkandung dalam norma dan nilai bukanlah hanya untuk meyakinkan, tetapi juga untuk menguasai, mengontrol, dan jika dirumuskan dalam bentuk yang lebih baik lagi, maka tujuannya adalah untuk menguasai dengan jalan meyakinkan. Sampai ke mana ia berhasil, dalam membentuk perilaku, sampai di sana pula ia mencapai tujuan kelas (Scott, 2000: 31). 
Hal tersebut berarti bahwa dalam struktur sosial sebuah masyarakat, kelas atas adalah mereka yang mendominasi, baik faktor ekonomi maupun penguasaan atas norma dan nilai yang dibentuknya. Sementara itu, kelas bawah adalah mereka yang dikuasai oleh elite melalui pelaksanaan norma dan nilai. Secara ekonomi, mereka juga tidak memiliki dan tidak menguasai faktor ekonomi. Di sini, antara kelas yang berkuasa dan tidak berkuasa oleh James C. Scott dipisahkan melalui sebutan "orang kaya dan orang miskin". Untuk memelihara kekuasaan, kelas yang berkuasa akan menjalankannya dengan mengakomodasi kepentingan orang-orang yang dikuasainya. Dengan demikian, apa yang disebut kekuasaan adalah sesuatu yang diperoleh melalui penguasaan atas faktor ekonomi serta norma dan nilai, yang terbungkus dalam sebuah hubungan yang hegemonis.

Dalam konteks komunitas pemulung Pandesari, penguasaan atas tanah yang dijadikan sebagai lahan bagi komunitas adalah penguasaan faktor ekonomi yang ada. Dalam perkembangan selanjutnya, kepala komunitas mendirikan sebuah tempat tinggal yang di dalamnya kemudian juga dihuni oleh pemulung, pemilah, atau penimbang yang menginginkan pekerjaan dan pemukiman. Proses tersebut menyebabkan kepala komunitas mampu menguasai faktor produksi berupa tenaga kerja. Begitu pula dengan norma dan nilai yang berlaku, bukanlah aturan berdasarkan atas kesepakatan bersama di antara semua penghuni, melainkan lebih merupakan representasi kekuasaan elite komunitas sebagai akibat dari penguasaan atas faktor produksi.

Kedua, konsep eksploitasi. James C. Scott (2000: 101-102) berasumsi bahwa eksploitasi pada masyarakat petani terjadi karena adanya dua kali masa tanam yang dilakukan melalui mekanisasi pertanian. Hubungan eksploitasi berjalan dalam hubungan antara elite komunitas, yaitu pengepul dengan anggota komunitas, yakni pemulung. Demikian pula dengan kelas elite yang mampu memanfaatkan hubungan tersebut menjadi hubungan yang eksploitatif, yang akhirnya mampu memberikan keuntungan berlebih kepadanya.

Ketiga, konsep perlawanan atau resistensi. James C. Scott mengungkapkan bahwa perlawanan dilakukan oleh petani penyewa terhadap pemilik lahan, disebabkan oleh sistem sewa dalam pengelolaan lahan pertanian ternyata membawa kerugian bagi petani penyewa. Sebaliknya, pihak pemilik lahan dapat memupuk keuntungan sebesarbesarnya dari hasil keringat petani penyewa. Oleh karena itu, pihak yang tereksploitasi ini kemudian melakukan perlawanan sebagai bentuk perjuangan kelas. Bentuk perlawanan petani ini dilakukan dalam bentuk perlawanan sehari-hari (everyday forms of resistance). Perlawanan yang dilakukan oleh kelas terdominasi ini tidak bertujuan untuk mendominasi sehingga perlawanan tidak perlu diarahkan pada sumber langsung perampasan (kelas yang mendominasi). Sepanjang tujuan orang-orang yang melawan tersebut adalah hanya untuk memenuhi kebutuhan fisik, makanan, tanah, atau pendapatan, dan melakukannya dalam keadaan yang relatif aman, maka mereka dapat hanya mengikuti garis perlawanan yang paling lunak (Scott, 2000: 47).

Dalam konteks yang berbeda, dalam komunitas pemulung Pandesari, perlawanan juga dilakukan melalui perlawanan seharihari, baik secara sembunyi-sembunyi maupun terang-terangan, yang dilancarkan oleh pemulung kepada pengepul yang menguasainya guna mendapatkan tingkat subsisten yang lebih aman. Ketika mereka menyadari bahwa kondisi mereka tereksploitasi, maka perlawanan secara sembunyi-sembunyi maupun terangterangan merupakan sebuah pilihan sadar bagi pemulung terhadap sistem yang eksploitatif dalam komunitasnya. Pada akhirnya, resistensi mengarah pada sebuah penciptaan sistem untuk bertahan hidup di kota.

Pertanyaan yang timbul adalah mengapa kerangka teori perlawanan yang 
dipakai dalam tulisan ini menggunakan analogi petani? Jawabannya karena bentuk perlawanan yang dilakukan, baik oleh petani penyewa maupun pemulung, memiliki risiko sosial yang paling rendah meskipun tidak bertujuan untuk mengambil alih faktor-faktor produksi yang dimiliki oleh elite komunitasnya. Dalam melakukan perlawanan ini, pemulung -sama halnya dengan petani penyewamereka masih mempertimbangkan kondisi dan keamanannya. Prinsip inilah yang serupa dengan prinsip yang dilakukan oleh petani, yakni etika subsistensi atau prinsip "dahulukan selamat". Begitu pula dengan pilihan pemulung untuk ambil bagian dalam komunitas juga merupakan bentuk dari prinsip "dahulukan selamat". Untuk memenuhi kebutuhan sehari-hari, kaum urban ini akan melakukan pekerjaan apapun, termasuk menjadi pemulung, asalkan terdapat pendapatan sekaligus pemukiman. Hal inilah yang mendasari penggunaan konsep petani desa yang diadopsi dalam realitas masyarakat kota.

Data dalam tulisan ini digali dengan menggunakan metode kualitatif. Adapun studi kasus dipakai sebagai pendekatan utama dalam penelitian. Model studi kasus tersebut bertujuan untuk menggambarkan secara deskriptif fenomena yang diteliti (Salim, 2001: 95). Sementara itu, studi kasus antara lain dpat didefinisikan sebagai "an empirical inquiry that investigates a contemporary phenomenon within its real-life context, when the boundaries between the phenomenon and context are not clearly evident" (Yin, 1984: 23).

Mereka yang menjadi narasumber tulisan ini adalah informan, yang merupakan pembicara asli yang berbicara dengan mengulang kata-kata, frasa, dan kalimat dalam bahasa atau dialeknya sebagai model imitasi dan sumber informasi (Spradley, 1997: 35). Informan adalah penghuni komunitas pemulung Pandesari, termasuk pengepul, pemulung, penimbang, dan pemilah. Dalam pengumpulan data, digunakan teknik wawancara tidak terstruktur dan pengamatan dengan peran peneliti sebagai "pengamat sebagai partisipan".

Dalam proses pencarian hingga pengolahan data, identitas informan, nama lokasi, nama daerah, dan nama sebutan komunitas yang asli dirahasiakan. Perahasiaan identitas disebut dengan confidentiality yang menurut Berg adalah "an active attempt to remove from the research records any elements that might indicate the subjects' identities" (2007: 79). Untuk merahasiakan identitas informan, nama lokasi, maupun daerah dilakukan dengan mengubah nama asli, dan menggantikannya dengan nama samaran atau "pseudonym". Maksud penggunaan nama samaran adalah untuk menjaga kerahasiaan dan menjamin keamanan informan dan komunitas yang menjadi narasumber. Secara keseluruhan terdapat 13 orang narasumber penelitian. Dengan rincian; sepasang suami istri dari pihak pengepul, 9 orang informan pemulung, seorang penimbang, dan seorang pengepul. Dengan melakukan wawancara mendalam dan pengamatan, data dapat diperoleh dari masing-masing informan tersebut.

Teknik analisis data yang digunakan adalah teknik yang dikemukakan oleh Miles dan Huberman. Analisis data ini terdiri dari tiga alur kegiatan yang terjadi secara bersamaan, yakni; pertama, reduksi data yang dilakukan sejak peneliti menyusun rancangan penelitian, maupun proses observasi awal, hingga berlangsungnya proses pengumpulan data di lingkungan komunitas. Kedua, dilakukan dengan penyajian data berupa data primer maupun sekunder. Ketiga, penarikan kesimpulan (Miles dan Huberman, 1992: 19).

\section{PEMBAHASAN \\ Komunitas Pemulung Pandesari sebagai Komunitas Politis}

Komunitas pemulung Pandesari merupakan sebuah lokasi tempat tinggal sekaligus penampungan sampah sementara. Komunitas ini didirikan pada tahun 1990 oleh Imam (72 tahun) yang menjadi kepala komunitas. Selain sebagai penampungan sampah sementara, tempat ini juga dijadikan 
sebagai tempat tinggal orang-orang yang bekerja sebagai pemulung. Tanah yang didiami oleh penghuni komunitas merupakan tanah yang disewa oleh Imam dari seorang pemilik tanah di kelurahan setempat. Biaya sewa yang wajib dibayarkan kepada pemilik tanah sebesar Rp 3.500.000/ tahun.

Komunitas tersebut menempati tanah dengan luas lebih dari $2000 \mathrm{~m}^{2}$. Untuk membaginya, tanah tersebut dikapling menjadi beberapa bagian dengan panjang sekitar $5 \mathrm{~m}$ dan lebar 2,5 m. Kemudian, di atasnya didirikan rumah yang selanjutnya dapat ditempati oleh keluarga-keluarga penghuni komunitas. Jumlah keseluruhan mencapai sekitar 40 unit rumah yang saling berhimpitan, yang dihuni oleh 38 keluarga dengan jumlah total penghuni sekitar 80 jiwa. Namun demikian, jumlah penghuni dapat berubah sewaktu-waktu karena penghuni bisa berpindah ke rumah baru, berpindah rumah ke sanak saudara, dan sebagainya.

Melalui pengamatan yang dilakukan, dapat diuraikan bahwa antara kepala komunitas dengan penghuni komunitas, atau dalam hal ini pengepul dan pemulung terjadi perbedaan dalam hal kepemilikan rumah dan fasilitas yang mereka tempati. Pengepul menjadi kelas yang menguasai sekaligus memiliki fasilitas yang ada dalam komunitas, sedangkan pemulung adalah kelas yang hanya menguasai rumah nonpermanen yang ditempatinya. Begitu pula dengan kondisi rumah yang berhimpitan dapat membawa implikasi secara politis. Selain dapat memudahkan kepala komunitas mengkoordinasipekerjanya, polapemukiman yang berhimpitan dapat memudahkannya melakukan fungsi pengawasan. Pengepul dapat dengan mudah mengendalikan dan mengontrol faktor produksi berupa pekerja.

\section{Klasifikasi Hirarkis dan Pembagian Kerja}

Penghuni komunitas pemulung Pandesari dapat dibedakan secara hirarkis menjadi dua kelas sosial, yaitu kelas elite komunitas dan anggota komunitas. Elite komunitas adalah pengepul, atau dalam hal ini adalah Imam, Sutri (istri Imam), beserta anggota keluarganya. Imam adalah kepala komunitas yang bertugas sebagai ketua, koordinator, dan pengepul sampah dari pekerja-pekerja yang bekerja untuknya, sedangkan Sutri adalah orang yang mengatur masalah keuangan dalam usaha yang dirintis suaminya. Jika diidentifikasi, elite komunitas adalah (1) golongan yang menguasai, baik faktor ekonomi berupa lahan, maupun faktor ekonomi berupa pekerja, dan (2) golongan yang memiliki wewenang atas terbentuknya norma dan nilai dalam komunitas.

Adapun golongan kedua adalah kelas anggota komunitas. Mereka adalah kelas yang secara hirarkis bergantung pada elite komunitas, tidak menguasai faktor ekonomi berupa lahan maupun tenaga kerja, juga tidak memiliki wewenang atas terbentuknya nilai dan norma dalam kehidupan komunitas. Golongan tersebut terdiri dari pemulung, pemilah, dan penimbang. Sebagian besar yang bekerja sebagai pemulung adalah laki-laki, sedangkan hanya sebagian kecil perempuan dewasa bekerja mencari sampah. Beberapa dari mereka lebih memilih untuk menjadi ibu rumah tangga, yang bertugas dalam urusan domestik, seperti memasak, mencuci, dan mengasuh anak.

Pemulung adalah anggota komunitas dengan jumlah terbesar, yaitu sekitar 35 kepala keluarga dengan dumlah keseluruhan adalah sekitar 60 orang. Hal ini berarti dalam satu keluarga dapat ditemui satu hingga tiga orang yang bekerja sebagai pemulung. Mereka yang bekerja di antaranya adalah ayah, anak laki-laki dewasa, dan beberapa ibu, dengan rata-rata usia antara 19 hingga 50 tahun.

Pemulung memiliki pekerjaan mencari dan mengumpulkan sampah. Mereka biasa bekerja mencari sampah dengan berkeliling pada tempat-tempat tertentu. Tempat-tempat seperti pasar, sepanjang aliran sungai, di sekitar ruko (rumah dan toko), perumahan warga, di lokasi Tempat Pembuangan Akhir (TPA), stasiun kereta api, maupun di lokasi proyek pembuatan bangunan merupakan 
tempat yang banyak dijadikan objek mencari sampah. Jam kerja mereka tidak tetap, namun dilakukan rata-rata antara pukul 06.00 WIB hingga 17.00 WIB, atau bahkan lebih, dan tanpa libur selama tujuh hari dalam seminggu. Biasanya, di sela-sela jam tersebut mereka pulang untuk beristirahat atau makan. Setelah beristirahat mereka melanjutkan kembali aktivitasnya mencari sampah.

Pembayaran atas upah yang diterima oleh pemulung bukan berdasarkan atas jam kerja, seperti mingguan atau bulanan, melainkan pada perolehan sampah yang telah dipungutnya. Jadi, pembayaran upah dilakukan layaknya transaksi jual-beli yang dapat dilakukan kapan saja. Jika diukur dari segi penghasilan, maka penghasilan rata-rata yang diterima pemulung dalam seminggu pun beragam, yaitu antara Rp 70.000 hingga Rp 120.000. Namun demikian, penghasilan yang diterima sangat tidak menentu dan bergantung pada jenis, mutu, dan banyak sampah yang mereka kumpulkan.

Pemilah adalah anggota komunitas yang memiliki pekerjaan memilah dan memisahkansampahyangtelahdikumpulkan oleh pemulung di dalam gudang. Pemilah hanya beranggotakan seorang laki-laki. Upah yang diterima pemilah lebih terjamin daripada pemulung, yaitu Rp 25.000/hari. Jam kerja yang dimiliki oleh pemilah juga lebih menentu, yaitu antara pukul 08.00 WIB hingga 16.00 WIB dengan hari kerja Senin hingga Sabtu, dan libur di Hari Minggu dan Jumat Legi. Adapun penimbang adalah orang yang bertugas menimbang sampah yang telah dipilah-pilah oleh pemilah dalam gudang. Penimbang hanya beranggotakan seorang laki-laki. Besarnya upah, jam, dan hari kerja yang dimiliki oleh penimbang pun sama dengan pemilah.

Selain pekerjaan tersebut, pemilah dan penimbang memiliki pekerjaan lain yang sama, yaitu melakukan pengepakan sampah berdasarkan kategori-kategori yang telah ditentukan sebelumnya. Setelah dikemas, sampah bisa diangkut dan dikirim kepada pengepul yang lebih besar yang berada di luar komunitas ini. Pemilah dan penimbang memiliki sebutan khusus dalam komunitas, seperti "pegawai", atau sering pula disebutkan dengan frase Bahasa Jawa; "pegawaine Imam", atau secara harfiah dapat diterjemahkan dengan "pegawainya Imam".

\section{Ketergantungan Pemulung atas Sarana Subsistensi}

Kelas yang berkuasa mampu menguasai kelas yang dikuasai melalui proses yang hegemonik. Artinya, penguasaan dijalankan melalui proses yang dapat mengakomodasi kepentingan kelas yang dikuasai. Hal itu tercermin melalui penyediaan lahan, tempat tinggal, atau pekerjaan oleh pengepul. Demi menunjang kelanggengan kekuasaan yang kuat, kelas elite komunitas telah membentuk sebuah jaringan sosial yang akan mendukung kekuasaannya. Jaringan sosial didapat sejak sebelum Imam mendirikan komunitas pemulung Pandesari. Imam banyak mendapatkan jaringan dari berbagai kalangan, seperti anggota DPRD, tentara, maupun pengacara. Setelah sekian tahun berlalu, akhirnya Imam mendirikan komunitas baru, yaitu pemulung Pandesari sekitar tahun 1990. Jaringan tersebut menjadi pelindung atau pemberi jaminan. Sebaliknya, keberadaan elite komunitas yang memiliki jaringan dan jaminan sosial akan ditopang oleh keberadaan anggota komunitas, seperti pemulung. Hubungan ini kemudian menciptakan hubungan timbal-balik antara pengepul dengan pemulung.

Pernyataan di atas diperkuat oleh pendapat beberapa informan. Alasan mereka adalah penghasilan sekaligus pemukiman. Dari pernyataan informan tersebut dapat digambarkan bahwa keputusan untuk menjadi penghuni komunitas adalah untuk mencari jaminan, baik secara sosial maupun ekonomi. Dalam bahasannya, Scott menyebut sebagai prinsip "dahulukan selamat". Prinsip ini merupakan konsekuensi dari suatu kehidupan yang begitu dekat dengan garis batas (Scott, 1981: 3-4).

Dengan adanya jaminan sosial, maka para pemulung harus menjadi klien bagi 
patron dalam komunitas. Patron adalah pihak atau orang yang berada dalam posisi untuk membantu klien-kliennya (Scott, 1981: 41). Artinya, seseorang ketika memutuskan untuk menjadi pemulung, secara langsung dirinya akan mengalami hubungan ketergantungan, akibat bantuan jaminan sosial yang disediakan pengepulnya. Dalam terminologi Scott, hal ini dijelaskan bahwa petani lebih menyukai satu sistem ketergantungan yang menempatkan patron melindungi klien terhadap kehancuran dalam tahun-tahun yang buruk (Scott, 1981: 62).

Keharusan bekerja sebagai pemulung, menurut informan, adalah pekerjaan yang membutuhkan "mental yang kuat", karena tak jarang mereka merasa malu dengan pekerjaannya. Keadaan tersebut merupakan bentuk prinsip "dahulukan selamat", lebih mendahulukan faktor ekonomi dari pada faktor lainnya. Akan tetapi, prinsip itu justru mengukuhkan posisi pengepul sebagai patron yang menjamin kehidupan pemulung. Hal ini diperkuat dengan hasil pengamatan dalam keseharian kehidupan mereka. Sebagai pemimpin dalam komunitas Pandesari, keluarga Imam selalu memberikan bantuan seperti pinjaman uang maupun pinjaman berupa peralatan makan, bagi para pemulung yang memiliki hajat atau keperluan, seperti pesta pernikahan, acara Tahlil, maupun selamatan kematian. Scott mengutarakan bahwa patron diharapkan dapat mensponsori pesta yang dilakukan oleh kliennya, meskipun juga bantuan ini mengandung unsur imbalan yang harus dibayarkan oleh klien di kemudian hari (1981: 63). Scott berasumsi bahwa tujuan patron memberikan bantuan kepada klien adalah agar posisinya dalam struktur sosial menjadi semakin kuat. Akibatnya, posisi patron akan selalu didukung oleh klien yang setia kepadanya.

Bantuan yang diberikan oleh pengepul merupakan sebuah bentuk piutang sosial. Bagi pemulung, piutang sosial merupakan hutang yang harus dikembalikan dalam wujud apapun yang mereka mampu. Jika pengepul telah memberikan bantuannya, maka mereka diharuskan untuk membalasnya di kemudian hari. Namun, andaikata tidak dapat mengembalikan hutang kepada pengepul, maka pemulung akan mendapatkan pelabelan sebagai “orang yang tidak tahu terima kasih", atau bahkan penghentian pemberian bantuan.

Singkatnya, kekuasaan kelas elite komunitas merupakan hasil dari hubungan patron-klien, yang tidak hanya diperoleh melalui penguasaan faktor ekonomi berupa lahan sewaan saja, namun juga didapatkan melalui jaminan sosial yang mampu disediakannya. Jaminan sosial yang dimiliki pengepul sebagai patron, merupakan faktor penting dalam proses mendapatkan kekuasaan. Karena pemulung merupakan klien yang mencari jaminan sosial, maka secara tidak langsung mereka akan lebih mengutamakan "dahulukan selamat" dengan menggantungkan diri pada pengepul. Setelah itu, kekuasaan dapat dipertahankan dengan norma yang diberlakukan bagi seluruh anggota komunitas, yang mengatur semua tindakannya.

\section{Eksploitasi Pengepul terhadap Pemulung}

Ketika elite komunitas mampu mendapatkan dan mempertahankan kekuasaan, dapat dipastikan anggota komunitas, seperti para pemulung, akan semakin bergantung pada elite komunitasnya. Jika kondisi tersebut berlanjut, maka konsekuensinya adalah pemulung dijadikan sebagai faktor ekonomi bagi pengepul. Merujuk pada pandangan Scott, apa yang terjadi disebabkan karena asuransi subsistensi merupakan satu-satunya cara untuk mengikat tenaga kerja (Scott, 1981: 9) sehingga dapat diidentifikasi bahwa asuransi subsistensi merupakan sarana untuk mendapatkan faktor produksi berupa tenaga kerja.

Proses eksploitasi yang terjadi dalam komunitas berjalan melalui kehidupan sehari-hari. Sebagai penyedia sarana 
subsistensi, pengepul dapat memerintahkan pemulung untuk bekerja kepadanya. Sebaliknya, pemulung yang menginginkan asuransi subsistensi dari pengepul, secara otomatis diharuskan untuk bersedia melakukan apapun. Untuk itu, seorang klien diharuskan untuk bekerja mencari sampah agar mendapat jaminan soial yang diinginkannya.

Lalu, bagaimana eksploitasi dalam komunitas pemulung ini terjadi? Dalam setiap kesempatan wawancara dengan informan didapatkan jawaban bahwa eksploitasi berjalan melalui mekanisme pemberian upah. Cecep mengungkapkan bahwa pendapatan dari aktivitas mencari sampah sudah tidak menentu. Dalam satu minggu informan berusia 48 tahun tersebut hanya bisa mendapatkan uang sebesar Rp 95.000 hingga $\mathrm{Rp} 115.000$. Selain itu, istri Cecep, Atun juga ikut mencari sampah. Atun harus berjalan kaki hingga jarak beberapa kilometer. Ketidak-pastian upah yang diterima merupakan tantangan tersendiri dalam aktivitasnya.

Tolo (55 tahun) juga menyatakan beratnya pekerjaan pemulung. Dia menjelaskan bahwa aktivitas sehari-hari mencari sampah dimulai pukul 07.00 hingga 12.00 WIB. Karena kondisi fisiknya yang semakin lemah, Tolo hanya bisa mencari sampah pada rentang waktu itu saja. Jika beruntung dan banyak sampah yang didapatkan, maka dalam satu hari dia bisa mendapatkan uang hingga mencapai $\mathrm{Rp}$ 50.000. Namun tak jarang pula, dia harus memeras tenaganya untuk mendapatkan uang $\mathrm{Rp} 50.000$ dalam waktu tiga hingga tujuh hari. Setelah sampah terkumpul, Tolo lalu menyetor dan menimbangnya di gudang.

Selain jumlah sampah, jenis dan mutu sampah juga menentukan harga beli yang diberikan pengepul. Meskipun sampah yang didapatkan berjumlah banyak, namun jika jenis sampah adalah sampah berharga murah dan kualitas rendah, maka upah yang diterima pemulung pun relatif rendah. Berikut ini disajikan daftar jenis sampah yang biasa dikumpulkan pemulung beserta harga belinya per kilogram. ${ }^{1}$

Tabel Daftar Jenis dan Harga Beli Per Kilogram Sampah

\begin{tabular}{|c|c|}
\hline Jenis Sampah & $\begin{array}{c}\text { Harga Beli per } \\
\mathrm{Kg}\end{array}$ \\
\hline Paku & $\operatorname{Rp} 1.500$ \\
\hline Kardus & Rp. 1.250 \\
\hline Kaleng bekas & Rp. 1.200 \\
\hline $\begin{array}{l}\text { Plastik berbentuk lembaran } \\
\text { (tas kresek) }\end{array}$ & Rp 500 \\
\hline Gelas bekas air mineral & Rp 6.000 \\
\hline $\begin{array}{l}\text { Plastik berbentuk padat } \\
\text { (seperti; gayung) }\end{array}$ & $\operatorname{Rp} 3.000$ \\
\hline Kertas koran dan buram & Rp 200 \\
\hline Kertas putih & $\operatorname{Rp} 1.500$ \\
\hline Besi & $\operatorname{Rp} 2.000$ \\
\hline Timah & $\operatorname{Rp} 6.000$ \\
\hline Tembaga & $\operatorname{Rp} 6.500$ \\
\hline Seng & $\operatorname{Rp} 10.000$ \\
\hline Alumunium & $\operatorname{Rp} 1.200$ \\
\hline Botol kecap (kaca) & $\operatorname{Rp} 100$ \\
\hline Botol minuman (kaca) & 500 \\
\hline Piring kaca & 250 \\
\hline
\end{tabular}

Eksploitasi menjadi semakin nyata ketika terungkap bahwa harga beli yang berlaku di komunitas Pandesari lebih murah dari pada di tempat jual beli sampah yang lain. Namun demikian, seluruh pemulung penghuni Pandesari tidak ada yang berani untuk menjual sampahnya di tempat lain, karena adanya aturan yang mengharuskan menjual sampah pada Imam saja. Konsekuensi bagi yang melanggar aturan adalah sebuah hukuman sosial yang akan diberikan oleh pengepul. Oleh karena itu, norma yang berlaku mengatur agar klien tetap memberikan legitimasi bahwa pengepul adalah patron yang memberikan jaminan sosial terhadapnya. Seorang klien diharuskan untuk patuh pada apa yang diperintahkan oleh patron, walaupun pada dasarnya kepatuhan tersebut dapat merugikan klien.

\footnotetext{
1 Harga beli yang tercantum dalam penelitian ini sewaktu-waktu dapat berubah.
} 
Uraian di atas lebih banyak menggambarkan kondisi pemulung, sedangkan diperlukan juga uraian mengenai kondisi pengepul. Namun karena akses atas informasi tersebut sangat dibatasi, maka data yang diperoleh hanya merupakan beberapa petunjuk. Sebagai petunjuk pertama, digunakanlah data mengenai keuntungan yang diterima pengepul dalam setiap bulan. Dari hasil wawancara yang dilakukan dengan Imam belum dapat diungkap berapa pendapatan atau keuntungan bersih yang diterima oleh pengepul. Keuntungan yang diperoleh pengepul hanya terungkap dapat digunakan untuk membayar berbagai kebutuhan seperti membayar upah para pegawainya (pemilah dan penimbang), membayar uang sekolah anak, hingga melunasi hutang. Petunjuk ini dinilai kurang detil sehingga diperlukan petunjuk lain. Dalam sebuah kesempatan wawancara terungkap bahwa keuntungan yang diperoleh bisa digunakan untuk melunasi hutang senilai Rp 70.000.000 dan dapat digunakan untuk membeli dua buah rumah senilai Rp 50.000.00 per buah pada tahun 90 -an.

Data di atas menunjukkan hubungan eksploitasi antara pengepul terhadap pemulung. Proses eksploitasi menempatkan pengepul sebagai kelas yang mengeksploitasi faktorproduksitenagakerjayangdikuasainya. Sementara itu, pemulung hanyalah faktor produksi yang tereksploitasi. Tata hubungan tersebut menunjukkan unsur-unsur ketidaksamaan dan paksaan yang sangat menonjol dibandingkan dengan tata hubungan lainnya, sehingga dapat dengan mudah dikenali sebagai hubungan yang lebih eksploitatif jika dilihat secara obyektif (Scott, 1981: 240). Ketidak-samaan dalam konteks tulisan ini dilihat melalui upah pemulung dengan jam kerja. Jerih payah dalam jam kerja yang telah dilakukan untuk mendapatkan sampah bukan merupakan suatu ukuran untuk menentukan upah. Upah hanya ditentukan oleh mutu, jumlah, dan jenis sampah yang telah dikumpulkan. Ketidak-samaan yang terjadi pada akhirnya akan membawa pada kondisi ketimpangan pendapatan antara pengepul dengan pemulung. Sementara itu, paksaan dalam konteks penelitian ini dilihat sebagai penegakan norma yang diberlakukan. Pengepul mengharuskan pemulung melakukan sesuatu yang telah menjadi norma sehingga apa yang dilakukan merupakan bentuk tingkah laku klien yang tunduk kepada patron.

Dalam asumsi Scott, eksploitasi memiliki dua ciri. Pertama, eksploitasi harus dilihat sebagai suatu tata hubungan antara perorangan, kelompok, atau lembaga. Adanya pihak yang mengeksploitasi mengimplikasikan adanya pihak yang dieksploitasi. Kedua, eksploitasi merupakan distribusi tidak wajar dari usaha dan hasilnya (Scott, 1981: 239). Berdasarkan dua ciri di tersebut, maka eksploitasi dalam konteks ini memenuhi dua ciri tersebut. Ciri pertama menempatkan elite komunitas yaitu pengepul, sebagai kelas yang mengeksploitasi pemulung. Ciri kedua dapat dilihat melalui upah yang tidak sebanding dengan jam kerja dan usaha yang dilakukan ketika proses mencari sampah. Ketidak-sebandingan atas apa yang diterima pemulung memberikan keuntungan atau "nilai lebih" bagi pengepul dalam proses produksi. Sementara itu, pemulung merupakan pihak yang dirugikan dariadanya mekanismetersebut. Pelaksanaan norma yang berlaku dalam komunitas pun berperan dalam penciptaan sistem yang terlembaga. Pemulung diharuskan untuk tunduk pada norma yang ada, sebagai bentuk kepatuhan klien terhadap patronnya.

\section{Resistensi: Konsekuensi atas Eksploitasi}

Adanya kondisi yang tidak menguntungkan karena eksploitasi, membuat anggota komunitas melakukan berbagai hal termasuk melakukan perlawanan terhadap sistem yang berlaku, seperti diungkapkan oleh salah seorang informan, Tini (54 tahun). Karena kondisi fisik yang tidak lagi prima, ia hanya bisa membuka warung kelontong di rumahnya dengan bantuan modal dari pengepul. Namun dalam perjalanannya, uang keuntungan warung justru tidak 
dimanfaatkan sebagaimana mestinya. Hingga akhirnya terungkap bahwa Tini memiliki banyak hutang di toko tempatnya membeli barang dagangan. Bahkan, Tini juga masih memiliki tanggungan hutang kepada Imam sebesar Rp 12.000.000.

Karena merasa telah memberikan jaminan sosial, maka sang patron akan mengharapkan tindakan kliennya sesuai dengan norma yang berlaku. Hal itu dikarenakan sistem yang selama ini diciptakan oleh Imam, telah dirusak oleh tindakan Tini. Namun dalam perkembangan selanjutnya, apa yang dilakukan oleh Tini mendapatkan ganjaran dari juragannya, yaitu diusir dari komunitas Pandesari.

Akibat eksploitasi yang berlaku, pemulung juga melakukan perlawanan dalam bentuk lain, yaitu secara diam-diam menjual sampah di pengepul lain yang memberikan harga beli sampah lebih tinggi daripada pengepul di komunitas itu. Yati (43 tahun), misalnya mengatakan bahwa beberapa pemulung pernah menjual sampah yang diperolehnya kepada pengepul lain yang memiliki harga beli relatif lebih tinggi dari pada pengepul Pandesari. Meskipun dilarang, menurut Yati tindakan ini tetap dilakukan pemulung dengan konsekuensi jika ketahuan akan diusir dari komunitas. Penjualan sampah kepada pengepul lain merupakan bentuk pembangkangan yang dilakukan untuk menyiasati harga beli yang murah dari juragan mereka. Penjualan sampah di tempat lain dilakukan untuk menyiasati kebutuhan hidup pemulung yang tidak dapat digantungkan semata-mata dengan menjual sampah kepada pengepul.

Data mengenai penjualan sampah kepada pengepul lain hanya bertumpu pada informasi yang telah disampaikan Yati. Sebab, untuk menelusuri siapa saja pemulung yang menjual sampah kepada pengepul lain adalah pekerjaan yang tidak mudah. Namun demikian, apa yang telah diutarakan Yati menggambarkan bahwa terjadi perlawanan dengan cara menjual sampah kepada pengepul lain yang memiliki harga beli yang relatif lebih tinggi.
Perlawanan atau resistensi pemulung muncul akibat dampak dari eksploitasi yang mereka alami. Oleh Scott, ini disebut dengan "eksploitasi normal, perlawanan normal" (2000: 38), bentuk perlawanan sehari-hari. Perlawanan yang dilakukan oleh pemulung tidak membutuhkan koordinasi dan bukan perlawanan yang bersifat makro. Perlawanan yang dilancarkan pun merupakan sebentuk kerjasama pribadi. Artinya, perlawanan yang dilancarkan Tini maupun pemulung yang menjual sampah pada pengepul lain tidak melibatkan seluruh pemulung. Akhir perlawanan tersebut dilakukan dengan menghindari setiap konfrontasi simbolis langsung dengan pihak penguasa (Scott, 2000: 40).

Untuk meredam perlawanan yang dilancarkan oleh pemulung, pengepul akan menjalankan sebuah cara yang disebut dengan represi rutin. Represi rutin adalah cara yang digunakan untuk meredam perlawanan (Scott, 2000: 362). Sebagai contoh represi rutin ini adalah pengusiran terhadap Tini dari Pandesari dan pengusiran pemulung yang menjual sampahnya kepada pengepul lain. Namun demikian, Scott memiliki asumsi bahwa sangat sulit untuk melakukan pembasmian perlawanan dengan menggunakan represi rutin (Scott, 2000: 362). Hal ini dikarenakan bentuk-bentuk perlawanan yang dilancarkan oleh pemulung akan memiliki bentuk yang sangat beragam. Keberagaman juga menunjukkan strategi yang diambil pemulung dalam menanggapi represi rutin. Keberagaman bentuk perlawanan, dapat dilihat berupa penyebaran gosip. Beberapa wawancara yang dilakukan dengan informan mengungkapkan gosip mengenai keburukan-keburukan sifat dari Imam dan keluarganya.

Scott menyatakan bahwa bentuk-bentuk gosip atau, dalam Bahasa Jawa disebut rasanrasan, sebagai bentuk perlawanan simbolis murni. Perlawanan ini memiliki bentuk gosip jahat, perusakan nama baik, pemberian nama julukan, maupun kabar-kabar angin. Gosip merupakan kisah yang diceritakan tentang pihak ketiga yang tidak hadir, begitu 
dilontarkan, ia menjadi cerita anonim tanpa asal-usul, namun banyak penyalurnya. Di balik setiap potong gosip yang tidak hanya sekedar berita, terdapat pernyataan tersirat tentang suatu peraturan atau norma yang telah dilanggar. Sesungguhnya hanya sebuah pelanggaran tingkah laku yang menjadikan suatu peristiwa bernilai untuk digunjingkan (Scott, 2000:372).

Menanggapi berbagai macam bentuk perlawanan yang dilakukan, Sutri menyebut para pemulung yang suka membangkang sebagai orang yang "wani selet wedi rai", "berani berhadapan dengan pantat, takut berhadapan dengan wajah". Dalam Bahasa Jawa, ungkapan ini berarti bahwa "di depan" seseorang mencitrakan diri sebagai orang yang patuh dan penuh rasa hormat, namun "di belakang", orang itu melakukan pembangkangan. Ungkapan ini digunakan untuk menyebutkan tingkah laku orang yang suka membangkang. "Wani selet wedi rai", merupakan bentuk represi rutin. Tujuannya untuk "menyerang balik" gosip yang disebarkan pemulung. Oleh Scott, ini disebut dengan "perang kata-kata" (Scott, 2000:320). Akan tetapi, apa yang diungkapkan Sutri justru semakin menegaskan bahwa memang terjadi perlawanan yang dilakukan pemulung.

Dari paparan di atas dapat disimpulkan bahwa untuk menghadapi eksploitasi, pemulung melakukan perlawanan. Proses antara perlawanan dan eksploitasi yang saling berbalas tersebut disebut dengan "eksploitasi normal, perlawanan normal". Perlawanan yang dilancarkan dilakukan dengan berbagai macam bentuk seperti menjual arisan, berhutang kepada pihak lain, dan menjual sampah kepada pengepul lain. Perlawanan juga dilakukan oleh pemulung dengan menyebarkan gosip yang berisi hal-hal negatif tentang pengepul. Untuk meredam perlawanan, pengepul melakukan apa yang disebut dengan represi rutin yang dilakukan dengan pengusiran terhadap pemulung, sedangkan "perang kata-kata" dijalankan untuk "menyerang balik" perlawanan berupa gosip.

\section{Pemilah dan Penimbang sebagai "Tangan Kanan" Elite Komunitas}

Pemilah dan penimbang masing-masing hanya terdiri dari satu orang. Seseorang bekerja sebagai pemilah bernama Andi, sedangkan seseorang lagi yang bekerja sebagai penimbang bernama Parmin, atau biasa dipanggil Min. Mereka bekerja di dalam gudang antara pukul 08.00 hingga 16.00 WIB. Andi bekerja kepada Imam sejak tahun 1993, sedangkan Min bekerja sejak tahun 1990, awal komunitas didirikan. Min adalah anak tiri Imam, dan Andi adalah orang yang telah dirawat oleh Imam sejak kecil. Dalam hal upah, pemilah dan penimbang lebih terjamin dari pada pemulung. Upah yang diterima pemilah dan penimbang Rp 25.000 setiap hari. Upah tambahan sebesar Rp 20.000 diterima pemilah dan penimbang setelah mengangkat sampah yang telah dikemas ke dalam bak truk, sebelum dikirim kepada pengepul besar. Selain itu, setiap hari mereka memperoleh makan dua kali.

Pekerjaan yang digeluti pemilah dan penimbang tidak dapat dimasuki atau dikerjakan oleh pemulung. Artinya, pemilah dan penimbang mendapat kepercayaan dari pengepul untuk melakukan pekerjaanpekerjaan yang mereka jalankan. Kepercayaan ini didapatkan oleh Andi dan Parmin karena mereka berdua adalah orang yang telah lama bekerja kepada pengepul, selain juga terdapat hubungan kekerabatan. Dalam sebuah kesempatan wawancara, Andi yang telah dirawat Imam sejak kecil, merasa mampu diberi kepercayaan dalam tugas sebagai pemilah sampah. Sementara bagi Parmin, bekerja untuk ayah tirinya juga merupakan bentuk tanggung jawab yang tidak bisa dipindah-tangankan kepada orang lain.

Posisi penimbang sedemikian vital sehingga bukan sembarang orang yang boleh mengambil alih posisinya. Kepercayaan inilah yang kemudian melahirkan wewenang dalam menjalankan pekerjaan sebagai pemilah dan penimbang. Konsekuensinya, penghasilan yang diterima juga lebih tinggi daripada pemulung. Oleh karena itu, pemilah 
dan penimbang tidak hanya diidentifikasi sebagai hasil dari spesialisasi kerja, namun lebih dari itu, keberadaan pemilah dan penimbang adalah anggota komunitas yang memiliki wewenang tertentu dalam kehidupan komunitas pemulung Pandesari. Hal ini mengindikasikan bahwa pemilah dan penimbang berperan dalam menopang posisi kelas yang menjaminnya, yaitu elite komunitas. Secara ekonomi, pemilah dan penimbang memiliki penghasilan relatif lebih stabil, yang berarti pula mempunyai tingkat keterjaminan ekonomi yang relatif lebih tinggi dari pada pemulung.

Temuanini menjadibahan tinjauanulang atas pernyataan-pernyataan yang telah ditulis Scott tentang pola hubungan "patron-klien", eksploitasi, dan resistensi. Kemunculan anggota komunitas seperti pemilah dan penimbang yang diberi wewenang dan kepercayaan elite komunitas menyiratkan bahwa terdapat mekanisme tertentu dalam mempertahankan kekuasaan. Dengan kepercayaan dan wewenang yang diberikan, pemilah dan penimbang menjadi "tangan kanan" dan bertugas dalam menjaga status quo yang dimiliki oleh elite kekuasaan. Di sini dapat disimpulkan bahwa data mengenai pemilah dan penimbang ini berusaha untuk melakukan kritik terhadap konsep yang telah ditulis oleh Scott. Hal ini menjadi menarik karena dalam penelitiannya, Scott belum mengidentifikasi adanya golongan -seperti halnya pemilah dan penimbangyang berfungsi untuk mempertahankan posisi elite kekuasaan, sedangkan dalam hubungan semacam ini, dibutuhkan golongan yang dapat dipercaya oleh elite kekuasaan untuk memperkuat kekuasaan. Hasil penelitian Scott hanya menyuguhkan argumen mengenai hubungan patron-klien yang berdampak pada hubungan eksploitasi dan resistensi antara pemilik lahan dengan petani penyewa.

\section{SIMPULAN}

Secara spesifik, tulisan ini memberikan uraian pola hubungan yang terjadi dalam komunitas pemulung, yang sejajar dengan masyarakat petani desa, yaitu hubungan patron-klien yang di dalamnya terdapat pola subsistensi, eksploitasi, dan perlawanan. Untuk meraih kekuasaan, pengepul menjalin hubungan "patron-klien" dengan anggota komunitasnya yaitu para pemulung. Hubungan ini menempatkan pemulung sebagai golongan yang membutuhkan asuransi subsistensi, sedangkan pengepul sebagai golongan penyedianya. Hubungan patron-klien berkonsekuensi pada terjadinya eksploitasi terhadap faktor produksi berupa pemulung. Eksploitasi ditunjukkan dalam proses penentuan upah yang diterima pemulung yang mengesampingkan jam kerja dan hanya didasarkan pada mutu, jumlah, dan jenis sampah yang didapatkan.

Eksploitasi yang terjadi memicu resistensi atau perlawanan dari pemulung terhadap pengepul. Untuk meredam perlawanan, pengepul melakukan represi rutin dan "perang kata-kata". Represi rutin dan "perang kata-kata" terjadi dengan saling berbalas, yang mengindikasikan pula bagaimana pola hubungan eksploitasi dan perlawanan mendapatkan tempat dalam hubungan patron-klien. Kehadiran pemilah dan penimbang sebagai anggota komunitas yang diberi kepercayaan dan wewenang tertentu oleh pengepul dapat diidentifikasi sebagai "tangan kanan", atau orang kepercayaan elite kekuasaan. "Tangan kanan" sangat dibutuhkan untuk memperkuat kekuasaan dalam pola hubungan yang penuh dengan perlawanan diam-diam. Konsep "tangan kanan" ini juga merupakan bentuk kritik terhadap konsep Scott dalam bahasan mengenai hubungan patron-klien. Pada tataran praktis, hal ini layak diberi perhatian khusus bagi pengambil kebijakan agar dapat melihat secara komperhensif pola hubungan sosialpolitis yang ada dalam komunitas miskin kota. Selanjutnya diharapkan, komunitas miskin kota tidak hanya dipandang sebagai 
penyandang masalah sosial, tetapi juga tergali potensi dan keberdayaannya.

\section{DAFTAR PUSTAKA}

Berg, B. L, 2007, Qualitative Research Methods for The Social Sciences. Boston: Pearson Education, Inc.

Gilbert, A. dan J. Gugler, 1996, Urbanisasi dan Kemiskinan Dunia Ketiga. Yogyakarta: Tiara Wacana.

Miles, M. B. dan A. M. Huberman, 1992, Analisis Data Kualitatif: Buku Sumber tentang Metode-Metode Baru. Jakarta: UI Press.
Salim, A, 2001, Teori dan Paradigma Penelitian Sosial (Pemikiran Norman K. Denzin, dan Egon Guba, serta Penerapannya). Yogyakarta: Tiara Wacana.

Scott, J. C, 2000. Senjatanya Orang-orang yang Kalah: Bentuk Perlawanan Sehari-hari Kaum Petani. Jakarta: Yayasan Obor Indonesia.

1981, Moral Ekonomi Petani, Pergolakan dan Subsistensi di Asia Tenggara. Jakarta: LP3ES.

Spradley, J. P, 1997, Metode Etnografi. Yogyakarta: Tiara Wacana Yogya.

Yin, R. K, 1984, Case Study Research: Design and Methods. Beverly Hills: Sage Publications. 